\title{
Differentiating Sources of Fecal Contamination to Wilderness Waters Using Droplet Digital PCR and Fecal Indicator Bacteria Methods
}

\author{
Daniel P. Pendergraph, MS ${ }^{1,2,3}$; John Ranieri, $\mathrm{BS}^{4}$; Lochlin Ermatinger, BA ${ }^{5}$; Adam Baumann, $\mathrm{MS}^{4}$; \\ Alexander L. Metcalf, $\mathrm{PhD}^{2,3}$; Thomas H. DeLuca, $\mathrm{PhD}^{3}$; Matthew J. Church, $\mathrm{PhD}^{4}$ \\ ${ }^{1}$ The Wilderness Institute, Franke College of Forestry and Conservation, University of Montana, Missoula, Montana; ${ }^{2}$ Human Dimensions Lab, \\ Franke College of Forestry and Conservation, University of Montana, Missoula, Montana; ${ }^{3}$ Franke College of Forestry and Conservation, \\ University of Montana, Missoula, Montana; ${ }^{4}$ Flathead Lake Biological Station, Division of Biological Sciences, University of Montana, Polson, \\ Montana; ${ }^{5}$ Department of Land Resources and Environmental Sciences, Montana State University, Bozeman, Montana
}

\begin{abstract}
Introduction-Human activity in wilderness areas has the potential to affect aquatic ecosystems, including through the introduction of microorganisms associated with fecal contamination. We examined fecal microorganism contamination in water sources (lake outlets, snowmelt streams) in the popular Absaroka Beartooth Wilderness in the United States. Although the region is remote, increasing human visitation has the potential to negatively affect water quality, with particular concern about humanderived microorganism fecal contaminants.

Methods-We used standard fecal indicator bacterial assays that quantified total coliform bacteria and Escherichia coli concentrations, together with more specific polymerase chain reaction-based microbial assays that identified possible human sources of fecal microorganisms in these waters.

Results-Total coliforms were detected at all lake outlets (21 of 21 sites), and E coli was detected at 11 of 21 sites. Droplet digital polymerase chain reaction assays revealed the presence of human fecesderived microorganisms, albeit at abundances below the limit of detection $(<10$ gene copies per milliliter of water) at all but 1 of the sampling sites.

Conclusions-Our results suggest low prevalence of water-borne pathogens (specifically E coli and human-derived Bacteroides) in this popular wilderness area. However, widespread detection of total coliforms, Bacteroides, and $E$ coli highlight the importance of purifying water sources in wilderness areas before consumption. Specific sources of total coliforms and $E$ coli in these waters remain unknown but could derive from wild or domesticated animals that inhabit or visit the Absaroka Beartooth Wilderness. Hence, although contamination by human fecal microorganisms appears minimal, human visitation could indirectly influence fecal contamination through domesticated animals.
\end{abstract}

Keywords: microbial source tracking, water quality, Absaroka Beartooth Wilderness, visitor impacts, environmental management, wilderness character

\section{Introduction}

Designated wilderness areas in the United States are unique in that there are restrictions on permanent facilities to manage visitor impacts and human waste. ${ }^{1}$ However, human visitation to these areas continues to

Corresponding author: Matthew J. Church, PhD, University of Montana, Flathead Lake Biological Station, 32125 Biostation Ln, Polson, MT 59860; e-mail: matt.church@umontana.edu.

Submitted for publication July 2020.

Accepted for publication April 2021. increase, ${ }^{2}$ creating challenges for managers seeking to minimize impacts of human activities on wilderness natural resources..$^{2-4}$ In particular, fecal contamination of wilderness water sources presents a growing problem, requiring managers to identify areas of potential contamination to protect public health. ${ }^{5}$ Outbreaks of illnesses associated with fecal bacteria (eg, diarrhea) have been documented in congested recreational sites in wilderness areas, ${ }^{6,7}$ with possible sources of fecal contaminants including livestock, dogs, wild animals, and humans. 
Fecal indicator bacteria (FIB) assays are often used to identify the presence of total coliform bacteria, fecal coliforms, and Escherichia coli in aquatic ecosystems. ${ }^{8}$ Coliform bacteria can be introduced from various sources, and although the occurrence of $E$ coli is frequently attributed to fecal contamination, many strains of $E$ coli are not pathogenic and are not associated with feces. ${ }^{8}$ Moreover, standard FIB tests do not discriminate among the potential sources (eg, wildlife or human) of these microorganisms. Therefore, increasingly, DNA and polymerase chain reaction (PCR)-based methods are used to aid microbial source tracking (MST), linking microbial pathogens to specific host sources. ${ }^{9-12}$

Bacteria belonging to the phylum Bacteroidetes are often used as targets in MST assays because of source specificity to mammalian guts and feces. ${ }^{12-15}$ Members of Bacteroides can comprise upwards of 26 to $36 \%$ of the gut microbiota, ${ }^{16,17}$ and several Bacteroides genetic markers have been developed and successfully applied in PCR assays targeting humans, cattle, pigs, and horses. ${ }^{9,10,12,13,18-20}$

Our study focused on potential fecal contamination of waters in the Absaroka Beartooth Wilderness (ABW) in south central Montana. The ABW is a mountainous wilderness area northeast of Yellowstone National Park. The region ranges in elevation from approximately $1.6 \mathrm{~km}$ to over $4.1 \mathrm{~km}$ and contains a network of subalpine forests and alpine tundra. With over $1100 \mathrm{~km}$ of trails, the area receives high recreational use, including backpacking and stock packing, but no livestock grazing. Most human visitation is concentrated around lakes and at water sources near popular summits. Backcountry campsites are required to be $>60 \mathrm{~m}$ from lakeshores, and popular campsite locations have been cataloged in a geospatial database maintained by the US Forest Service for over $20 \mathrm{y}$. We sought to examine the occurrence of total coliform and $E$ coli in ABW water sources adjacent to backcountry camping areas and use MST methods to quantify members of Bacteroides derived from human feces.

\section{Methods}

\section{STUDY AREA AND SAMPLING SITES}

We selected a total of 23 sampling locations within the ABW (21 remote alpine lake outlets and 2 snowmelt streams) using geospatial information on campsite condition and popular recreational sites. Sampling sites were identified using ArcMap (version 10.5.1), overlaying campsite point locations with a wilderness-wide opportunity class layer representing 3 zones of recreational use: 1) pristine, 2) primitive, and 3) transition zones. Pristine zones were those with negligible anthropogenic influence, primitive zones were those with measurable anthropogenic influence, and transition zones were those where human impacts were moderate to substantial. All of our sampling was done within the transition zone, between 4.5 and $24 \mathrm{~km}$ from main trailheads (Figure 1).

\section{WATER SAMPLING, FIB DETECTION, AND DNA EXTRACTION}

Water samples from 21 different alpine lake outlets and 2 snowmelt streams were collected in triplicate over $13 \mathrm{~d}$ in July and August 2018 (Table 1). Water samples were placed into sterilized 250-mL polypropylene bottles and transported to the laboratory in the dark and on ice. In the laboratory, samples were stored at $4^{\circ} \mathrm{C}$ until processing (within $48 \mathrm{~h}$ of sample collection). Two 100-mL aliquots of sample water from each of the triplicate $250-\mathrm{mL}$ sample bottles were vacuum filtered onto separate $47-\mathrm{mm}$ diameter, $0.45-\mu \mathrm{m}$ pore size (mixed cellulous ester) gridded, pre-sterilized filters (Millipore Sigma, Burlington, MA). One of these filters was used for total coliforms and $E$ coli analyses, and the other filter was used for subsequent extraction of DNA. No filter was processed for DNA from Sylvan Lake, and only filters for subsequent extraction of DNA were collected from the 2 snowmelt streams.

Filters for FIB analyses were placed in M-ColiBlue24 broth petri dishes and incubated at $35^{\circ} \mathrm{C}$ for $24 \mathrm{~h}$ (Millipore Sigma). Colony-forming units (CFUs) were quantified by counting and recording the number of red (non- $E$ coli coliforms) and blue ( $E$ coli coliforms) plateforming colonies. Total coliforms were calculated as the sum of red and blue colonies.

DNA was extracted from filters using the MasterPure DNA Purification kit (Lucigen Corporation, Middleton, WI). Triplicate blank filters (ie, no sample filtered onto them) were processed alongside samples. Filters were transferred from $15-\mathrm{mL}$ centrifuge tubes to $2-\mathrm{mL}$ microcentrifuge tubes containing $600 \mu \mathrm{L}$ of a cell lysis solution and $100 \mu \mathrm{L}$ of $0.1-\mathrm{mm}$ and $100 \mu \mathrm{L}$ of $0.5-\mathrm{mm}$ glass beads. The tubes containing filters were frozen at $-80^{\circ} \mathrm{C}$, thawed, and placed into a mechanical bead beater for $2 \mathrm{~min}$, followed by the addition of proteinase-K (50 $\mu \mathrm{g} \cdot \mu \mathrm{L}^{-1}$ final concentration). Samples were incubated at $65^{\circ} \mathrm{C}$ for $15 \mathrm{~min}$ and placed on ice for 3 to $5 \mathrm{~min}$, and DNA was extracted following the MasterPure DNA Purification kit protocols. DNA was resuspended in $100 \mu \mathrm{L}$ of nuclease-free water and stored at $-80^{\circ} \mathrm{C}$.

\section{DROPLET DIGITAL PCR FOR DETECTION OF UNIVERSAL AND HUMAN-SPECIFIC BACTEROIDES GENE MARKERS}

We used 2 different droplet digital PCR (ddPCR) assays: one targeting bacteria belonging to the genus Bacteroides 


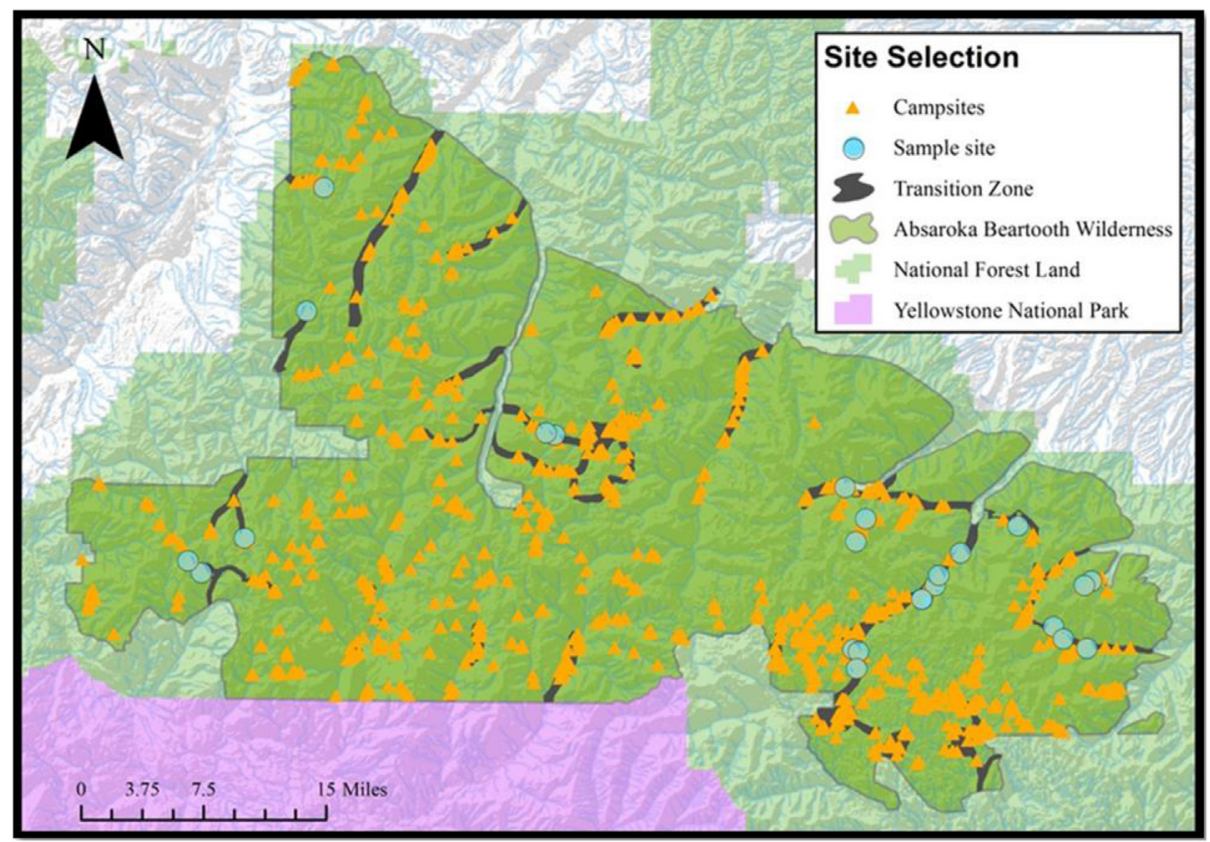

Figure 1. Sampling sites in the Absaroka Beartooth Wilderness. Backcountry campsites are indicated with orange triangles, and sampling sites for this study are indicated with blue circles.

and another specific to members of Bacteroides known to be associated with human feces. Both assays relied on previously published MST PCR methods. ${ }^{9,18}$ Two different pairs of PCR primers were used for each assay (Table 2): The AllBac primer pair was designed to amplify 16S rRNA genes of members of Bacteroides, inclusive of those previously recovered from mammalian feces, ${ }^{13,18}$ and the BacH primer pair targets $16 \mathrm{~S}$ rRNA genes from the HF183 cluster of human feces-associated Bacteroides. ${ }^{9,10,14,21,22}$ ddPCR assays were applied to sites where $E$ coli was detected using the FIB assays (excluding Sylvan Lake). We also used both ddPCR assays on samples collected from 3 lake outlets (Diamond, Rainbow, September Morn) where no E coli was detected but total coliform abundances were relatively high. Finally, both ddPCR assays were used on the samples collected from the 2 snowmelt streams.

Triplicate filter extracts from the lake outlets and snowmelt streams were analyzed by ddPCR using a QX200 Droplet Digital PCR System (Bio-Rad Laboratories, Hercules, CA). Each ddPCR reaction (20 $\mu \mathrm{L}$ total) contained EvaGreen Supermix (Bio-Rad Laboratories), nuclease-free water, DNA extract, and $0.18 \mu \mathrm{M}$ (final concentration) of each primer. Triplicate controls (with no added DNA) were included as negative controls. Filter blank DNA extracts were also analyzed in triplicate to estimate the detection limits associated with both ddPCR assays (see description in Statistics subsection). PCR reaction mixes were combined with droplet generation oil specific for EvaGreen, and droplets were generated using the droplet generator (Bio-Rad Laboratories). Droplets (40 $\mu \mathrm{L}$ total, including PCR reaction mix and oil) were transferred by multichannel pipettor into $0.2-\mathrm{mL}$ 96-well PCR plates. Plates were heat sealed and placed in a BioRad C1000 thermal cycler.

Amplification conditions were as follows: $95^{\circ} \mathrm{C}$ for 6 min, followed by 40 cycles of $95^{\circ} \mathrm{C}$ for $30 \mathrm{~s}, 61^{\circ} \mathrm{C}$ for $30 \mathrm{~s}$, and $72^{\circ} \mathrm{C}$ for $45 \mathrm{~s} .{ }^{13}$ A QX200 Droplet Reader (Bio$\mathrm{Rad})$ was used to quantify droplet specific fluorescence. The fluorescence amplitude threshold was manually adjusted to distinguish positive droplets from those that demonstrated no amplification (negative droplets). We excluded reactions with $<10,000$ accepted droplets from subsequent analyses $(n=3)$. Gene abundances (copies per milliliter of sample water) were quantified for each sample using the manufacturer's software (QuantaSoft, Bio-Rad Laboratories).

\section{STATISTICS}

The method detection limit (MDL) of the ddPCR assays was defined as the lowest number of genes that could be 
Table 1. Elevation, distance to trailhead, number of campsites, groundcover, and types of use for all sites surveyed in this study

\begin{tabular}{|c|c|c|c|c|c|c|}
\hline Sampling site & Date sampled (2018) & Elevation $(m)$ & $\begin{array}{l}\text { Distance to } \\
\text { trailhead }(\mathrm{km})\end{array}$ & $\begin{array}{l}\text { No. of established } \\
\text { campsites }^{a}\end{array}$ & Ground cover $^{b}$ & Use type ${ }^{c}$ \\
\hline Bald Knob & Jul 22 & 2871 & 12 & 11 & Rock & Foot, stock \\
\hline Diamond & Aug 12 & 2982 & 13 & 1 & Alpine tundra & Foot, stock \\
\hline Elbow & Jul 17 & 2664 & 11.2 & 5 & Open forest & Foot, stock \\
\hline Elk & Jul 29 & 2071 & 5 & 16 & Open forest & Foot, stock \\
\hline Fish & Jul 23 & 2732 & 8 & 2 & Forest, meadow & Foot, stock \\
\hline Horseshoe & Aug 14 & 2922 & 11.2 & 8 & Alpine tundra & Foot \\
\hline Keyser Brown & Aug 4 & 2650 & 11.2 & 9 & Open forest & Foot, stock \\
\hline Knox & Jul 23 & 2584 & 5.6 & 9 & Open forest & Foot, stock \\
\hline Lake at Falls & Jul 29 & 2499 & 14.5 & 5 & Open forest & Foot, stock \\
\hline Lake Gertrude & Aug 3 & 2924 & 7 & 4 & Forest, meadow & Foot, stock \\
\hline Lost & Aug 4 & 2583 & 8 & 18 & Open forest & Foot, stock \\
\hline Mystic & Jul 18 & 2337 & 5 & 44 & Open forest & Foot, stock \\
\hline Ouzel & Jul 22 & 2870 & 11.6 & 7 & Rock & Foot, stock \\
\hline Pine Creek & Jul 11 & 2801 & 8 & 14 & Forest, meadow & Foot \\
\hline Rainbow & Jul 29 & 2376 & 13.6 & 23 & Open forest & Foot, stock \\
\hline Rimrock & Jul 29 & 2317 & 9.6 & 5 & Rock & Foot \\
\hline Russell & Jul 22 & 2667 & 9.6 & 9 & Open forest & Foot, stock \\
\hline September Morn & Aug 4 & 3005 & 11.2 & 13 & Open forest & Foot, stock \\
\hline Sylvan & Jul 28 & 2799 & 9.6 & 3 & Forest, meadow & Foot, stock \\
\hline Thompson & Jul 12 & 2447 & 9.6 & 16 & Open forest & Foot, stock \\
\hline Timberline & Aug 3 & 2985 & 8 & 14 & Forest, meadow & Foot, stock \\
\hline Snowmelt stream 1 & Aug 22 & 3547 & 11.2 & 5 & Alpine tundra & Foot \\
\hline Snowmelt stream 2 & Aug 22 & 3642 & 16 & 3 & Alpine tundra & Foot \\
\hline
\end{tabular}

${ }^{a}$ The US Forest Service does not designate campsites in this area, but it monitors well-established but illegal camping sites.

${ }^{b}$ Ground cover designations defined by US Forest Service monitoring.

${ }^{c}$ Use-type: Foot refers to human foot traffic; foot and stock refers to both human and stock animal traffic.

distinguished based on replicate $(n=4)$ amplification of the filter blank DNA extracts. We estimated the MDL for each assay as

$M D L=$ Mean $_{\text {blank }}+3 \times S D_{\text {blank }}$

We defined the target gene as "present" if 1 or more of the triplicate ddPCR reactions amplified above the detection limits after 40 cycles. We quantified gene abundances only for those samples for which all triplicate ddPCR reactions amplified above the detection limits. Data are presented as mean \pm SD with range.

Least-squares linear regression analyses of square root transformed count data were used to examine relationships between CFUs of coliform and $E$ coli and between CFUs and site-specific characteristics (eg, elevation, distance from trailhead). Given the large number of 0 values (for the FIB assays) or values below the MDL (for ddPCR assays), data were square root transformed as

$y_{t}=(y+0.5)^{1 / 2}$

where $y_{t}$ is the transformed variable, $y$ is the measured property (eg, CFUs, gene abundances), and 0.5 is a constant. For those sites with gene abundances below the MDL, we assumed $y=0$ before transforming; for those sites where total coliform CFUs were above the upper threshold for accurate quantification ( $>200 \mathrm{CFUs}$ ), we assumed $y=200$ before transformation.

\section{Results}

\section{TOTAL COLIFORM AND E COLI OCCURRENCES}

Total coliforms were found in all 21 of the lake outlets sampled, and $E$ coli was found in approximately half (11 of 21) of the sampled sites. Total coliform CFUs ranged from 27 to $>200$ CFUs per $100 \mathrm{~mL}$ of water, whereas $E$ coli ranged from undetectable to $23 \mathrm{CFUs}$ per $100 \mathrm{~mL}$ of lake outlet water (Figure 2, Table 3). Total coliform levels of $>100 \mathrm{CFUs}$ per $100 \mathrm{~mL}$ of lake water were found in 14 of the $21(67 \%)$ lake outlet sites sampled (Table 3 ). Total coliform and $E$ coli CFUs were correlated across the various sampling sites (least-squares linear regression, $\mathrm{R}^{2}=0.26, P=0.018$ ); however, neither total coliform nor $E$ coli $\mathrm{CFUs}$ were correlated with site-specific properties such as elevation, distance from trailhead, or number of established campsites (leastsquares linear regressions, $P>0.05$ ). 
Table 2. Polymerase chain reaction primers used for microbial source tracking analyses

\begin{tabular}{lllcc}
\hline Target & Primer & Sequence & Amplicon size (bp) & Ref. \\
\hline Universal Bacteroides & AllBac 296f & 5'-GAGAGGAAGGTCCCCCAC -3' & 116 & 17 \\
& AllBac 412r & 5'-CGCTACTTGGCTGGTTCAG -3' & & \\
Human Bacteroides & BacH_f & 5'-CTTGGCCAGCCTTCTGAAAG -3' & 93 & \\
& BacH_r & 5'-CCCCATCGTCTACCGAAAATAC-3' & & \\
\hline
\end{tabular}

\section{UNIVERSAL AND HOST-SPECIFIC BACTEROIDES MST}

The amplitudes of fluorescence (in relative fluorescence units [RFUs]) for droplets binned as positive for the AllBac and $\mathrm{BacH}$ assays were 1.7- and 1.6-fold greater, respectively, than fluorescence amplitudes of the negative droplets. The amplitude of fluorescence for positive droplets in the AllBac assay was 15,571 11195 (11,628-17,579) RFUs, whereas the fluorescence amplitude of negative droplets was $9247 \pm 773$ (8044-11,026) RFUs. The fluorescence amplitude of the positive droplets for the $\mathrm{BacH}$ assay was somewhat lower at $9206 \pm 2849(6270-19,885)$ RFUs, with negative droplets at $5799 \pm 1030$ (4129-9971) RFUs. The number of accepted droplets for both assays was $15,043 \pm 1877$ (10,404-18,558). The MDL for the BacH ddPCR assay was 18 copies per ddPCR reaction, equivalent to 9 copies per milliliter of lake water, whereas the MDL for the AllBac ddPCR assay was 42 copies per reaction, equivalent to approximately 21 copies per milliliter of lake water.

AllBac genes were present in all of the sites examined by ddPCR, with gene abundances quantifiable in 11 of 15 sites (Table 3). For those sites where gene abundances were quantifiable, AllBac gene abundances ranged from $5 \times 10^{3}$ to $131 \times 10^{3}$ genes per $100 \mathrm{~mL}$ of sampled water, with peak abundances observed in the same 2 lakes where $E$ coli abundances were greatest (Lost and Keyser Brown lakes; Table 3). One of the snowmelt streams sampled near the base of Granite Peak also contained high abundances of the AllBac gene targets, with AllBac gene targets below the limit of detection in the other snowmelt stream sampled (Table 3).

Human-associated Bacteroides were found in very low abundances at all sites tested. BacH genes targets were present, but not quantifiable, at 52\% (7 of 15 sites) of the sites examined. Only 1 of the sampled sites (Elk Lake) had quantifiable but relatively low $\mathrm{BacH}$ gene abundance (Table 3). Elk Lake was notable as the site closest $(4.8 \mathrm{~km})$ to the main trailhead into the ABW and hence likely receives the most visitation of any of the sites sampled. All sites that tested positive for the presence of BacH gene targets also tested positive for the presence of AllBac gene targets. Neither of the snowmelt streams sampled contained quantifiable abundances of $\mathrm{BacH}$ gene targets (Table 3).

Based on least-squares linear regressions of the square root transformed data, total coliform CFUs and the AllBac gene abundances were correlated $\left(R^{2}=0.57\right.$, $P=0.004$ ); however, there were no significant relationships between the AllBac and BacH gene abundances or between AllBac abundances and any of the site-specific environmental properties (ie, elevation, distance from trailhead, number of established campsites; least-squares linear regressions; $P>0.05$ ).

\section{Discussion}

By leveraging culture-based FIB assays and culture-independent MST assays, we evaluated the spatial distribution and potential sources of fecal bacteria in selected ABW waters. Total coliforms were present in all of the lake outlets sampled, with positive occurrence of $E$ coli at $52 \%$ of these sites. The highest $E$ coli CFUs were found in lake outlets that are popular recreational water sources and accessible to stock animals and human foot traffic. Total coliform and $E$ coli counts were positively related, suggesting that for these waters, the occurrence of elevated $E$ coli covaries with abundances of total coliforms. Use of both FIB and PCR-based assays to examine fecal contamination of $\mathrm{ABW}$ waters revealed that in some cases, despite testing positive for the presence of $E$ coli, human-derived Bacteroides were not present. These results point to other possible sources of fecal contaminants, including animals (wild or domesticated).

Our study highlights the utility of combining FIB and MST methods for discerning possible sources of feces-associated microorganism contaminants. For example, we did observe a weak but significant positive relationship between the FIB-derived total coliform CFUs and AllBac gene abundances, suggesting the presence of mammalian Bacteroides may be related to increased prevalence of total coliform bacteria. However, there were no clear patterns linking those lakes with high CFUs or Bacteroides gene abundances to 
A

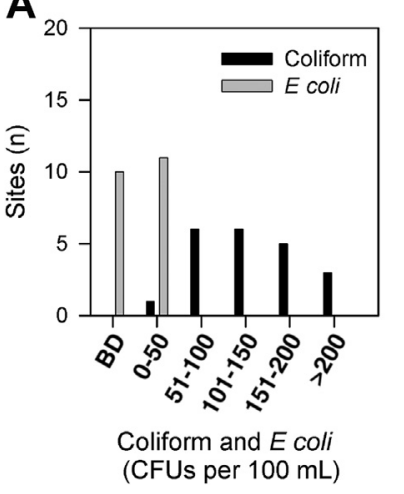

B

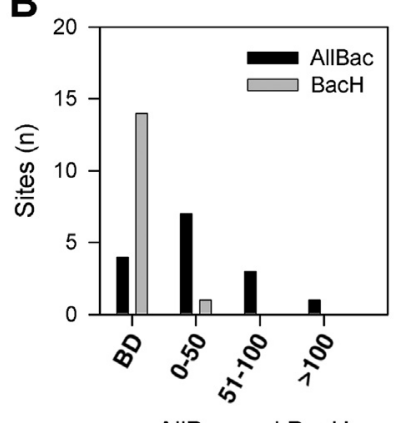

AllBac and $\mathrm{BacH}$ $\left({ }^{*} 10^{3}\right.$ genes per $\left.100 \mathrm{~mL}\right)$

Figure 2. Histograms of colony-forming units (per $100 \mathrm{~mL}$ of water) for total coliforms and $E$ coli (panel A) and ddPCR quantification of Bacteroides gene abundances for AllBac and $\mathrm{BacH}$ gene targets (panel B). $\mathrm{BD}=$ below limits of detection.

their surrounding environment or use types. Moreover, there were no apparent relationships between Bacteroides gene abundances or coliform CFUs and landscape types (eg, open forest, meadow, alpine tundra), elevation, or distance to trailhead. The extent to which variations in the local environment or watershed influenced the resulting microorganism distributions remains unclear; however, pack or domesticated animals may have contributed to the presence of coliform bacteria and Bacteroides.

Use of the AllBac ddPCR assay revealed widespread occurrence of members of Bacteroides. These microorganisms can be dominant members of ruminant, human, and waterfowl gut microbiomes ${ }^{14,21,23}$; thus, the occurrence of these microorganisms could indicate fecal contamination from various sources. We detected the presence of human feces-associated Bacteroides at 7 of the 15 of the sampling sites, but in all but 1 of these sites (Elk Lake) abundances were too low to quantify. Elk Lake was the lowest elevation site sampled, the closest to the trailhead $(4.8 \mathrm{~km})$, and it lies downstream of lakes that also tested positive for the presence of human-derived Bacteroides using the ddPCR assay. Thus, although most lakes in the ABW had very low human feces contamination, we did observe the presence of human-derived microorganisms in waters from highly trafficked areas.

We also sampled 2 snowmelt streams near Granite Peak, Montana's highest point and a popular summit within the ABW. The scarcity of water around Granite Peak creates congested basecamp areas that place disproportionate pressures on adjacent water resources. Prior studies on wilderness waters noted that both total coliform and $E$ coli counts correlated with periods of

peak human visitation. ${ }^{24-26}$ Both of the snowmelt streams tested positive for the presence of enteric members of Bacteroides, and human feces-associated Bacteroides were found in 1 of these streams. We attribute these findings to fecal contamination from various sources, including wildlife and human fecal bacteria. The detection of human-derived fecal bacteria in 1 of the 2 snowmelt streams emphasizes that future studies should include sampling of running waters in this region.

Although use of culture-based FIB- and PCR-based MST methods revealed that several lakes in the ABW appear to be influenced by fecal microorganism contaminants, for most lakes we were unable to identify sources of these potential contaminants. The humanspecific fecal indicator MST assay indicated that most of these lakes received little fecal input from humans. These results highlight the utility of combining more traditional FIB assays with emerging MST methods for information on both the occurrence and specific sources of microorganism contaminants to aquatic systems.

\section{LIMITATIONS}

A limitation in this study was the relatively high MDLs estimated for both ddPCR assays. Detection limits for both assays were somewhat higher than has been previously reported for quantitative PCR-based MST methods $^{27}$; the detection limits for the ddPCR assay derive from any amplification in the blanks, together with the volume of water filtered to concentrate microorganism biomass. We processed relatively small volumes of water for subsequent extraction of DNA, constrained in part by the remote locations and the need to transport water back to the laboratory. We also did not include PCR inhibition controls as part of our ddPCR analyses; hence, we do not have information on the extent to which the presence of inhibitors may have resulted in underestimation of the target gene abundances. In addition, our sampling was restricted to a single summer season; hence, we do not have information on how seasonal- to episodic-scale changes in the local environment (eg, rainfall, snowfall) might affect the introduction of fecal contaminants to these waters.

\section{Conclusions}

Our results suggest relatively low prevalence of waterborne pathogens (specifically $E$ coli and human-derived Bacteroides) in this popular wilderness area. The sources of total coliforms and $E$ coli to these waters are unknown but could derive from wild or domesticated animals that inhabit or visit the ABW. Hence, increased human 
Table 3. Occurrence of total coliform and $E$ coli CFUs and detectable occurrences of AllBac and BacH gene markers in lake outlets and snowmelt streams sampled in the Absaroka Beartooth Wilderness

\begin{tabular}{|c|c|c|c|c|c|c|}
\hline $\begin{array}{l}\text { Sampling site } \\
\text { (lake } \\
\text { outlets and } \\
\text { streams) }\end{array}$ & $\begin{array}{l}\text { Total coliform } \\
(\text { CFUs per } \\
100 \mathrm{~mL})\end{array}$ & $\begin{array}{l}\text { E coli } \\
(C F U s \\
\text { per } 100 \\
m L)\end{array}$ & $\begin{array}{l}\text { AllBac gene } \\
\text { abundances } \\
\left(\times 10^{3} \text { copies }\right. \\
\text { per } 100 \mathrm{~mL})\end{array}$ & $\begin{array}{l}\text { AllBac } \\
\text { present? }\end{array}$ & $\begin{array}{l}\text { BacH gene } \\
\text { abundances }\left(\times 10^{3}\right. \\
\text { copies } \\
\text { per } 100 \mathrm{~mL})\end{array}$ & $\begin{array}{l}\text { BacH } \\
\text { present? }\end{array}$ \\
\hline Bald Knob & 89 & 0 & NA & NA & NA & NA \\
\hline Diamond & 144 & 0 & $5.0 \pm 0.7$ & Yes & $\mathrm{BD}$ & No \\
\hline Elbow & 93 & 0 & NA & NA & NA & NA \\
\hline Elk & 152 & 2 & $33 \pm 19$ & Yes & $3.3 \pm 2.2$ & Yes \\
\hline Fish & $>200$ & 0 & NA & NA & NA & NA \\
\hline Horseshoe & $>200$ & 1 & $15 \pm 19$ & Yes & $\mathrm{BD}$ & No \\
\hline Keyser Brown & $>200$ & 5 & $96 \pm 56$ & Yes & $\mathrm{BD}$ & No \\
\hline Knox & 73 & 1 & $78 \pm 29$ & Yes & $\mathrm{BD}$ & No \\
\hline Lake at Falls & 142 & 1 & $29 \pm 2.2$ & Yes & $\mathrm{BD}$ & Yes \\
\hline Lake Gertrude & 174 & 1 & $20 \pm 11$ & Yes & $\mathrm{BD}$ & No \\
\hline Lost & 192 & 23 & $92 \pm 48$ & Yes & $\mathrm{BD}$ & Yes \\
\hline Mystic & 85 & 0 & NA & NA & NA & NA \\
\hline Ouzel & 62 & 0 & NA & NA & NA & NA \\
\hline Pine Creek & 27 & 0 & NA & NA & NA & NA \\
\hline Rainbow & 82 & 0 & $\mathrm{BD}$ & Yes & $\mathrm{BD}$ & Yes \\
\hline Rimrock & 124 & 1 & $\mathrm{BD}$ & Yes & $\mathrm{BD}$ & Yes \\
\hline Russell & 127 & 1 & $14 \pm 4.3$ & Yes & $\mathrm{BD}$ & No \\
\hline September Morn & 162 & 0 & $15 \pm 3.2$ & Yes & $\mathrm{BD}$ & No \\
\hline Sylvan & 180 & 4 & NA & NA & NA & NA \\
\hline Thompson & 129 & 0 & NA & NA & NA & NA \\
\hline Timberline & 149 & 2 & $\mathrm{BD}$ & Yes & $\mathrm{BD}$ & Yes \\
\hline Stream 1 & NA & NA & $\mathrm{BD}$ & Yes & $\mathrm{BD}$ & Yes \\
\hline Stream 2 & NA & NA & $131 \pm 11$ & Yes & $\mathrm{BD}$ & No \\
\hline
\end{tabular}

Presence of target gene indicates detectable but not quantifiable genes (ie, at least 1 sample from the triplicate ddPCR reactions amplified; "No" indicates none of the triplicate polymerase chain reaction reactions amplified above the lower limit of detection). Mean \pm SD of triplicate analyses from each lake outlet or snowmelt stream. BD indicates gene abundances below detection $(<900$ gene copies per $100 \mathrm{~mL}$ of lake water for BacH and $<2100$ gene copies per $100 \mathrm{~mL}$ of lake water for AllBac). NA indicates sample not analyzed.

visitation to the $\mathrm{ABW}$ could have indirect impacts on water quality via fecal contamination attributable to domesticated animals. Furthermore, widespread occurrence of total coliforms, Bacteroides, and $E$ coli highlights the importance of purifying water sources in wilderness areas before consumption.

Acknowledgments: This study benefited by input from A. Wood, K. Crootof, K. Barker, J. Zimmer, C. Neppl, L. Oswald, E. Bilbrey, and the US Forest Service. We thank the Franke College of Forestry and Conservation, the Human Dimensions Lab, L. Gerloff, and the Wilderness Institute at the University of Montana; W.A. Sigler and the Zabinski Lab at Montana State University; and Dr. R.O. Hall and T. Bansak at the Flathead Biological Station. The comments of 2 reviewers and the editor substantially improved this work.

Author Contributions: Study concept and design (DPP, MJC, ALM, THD); acquired data (DPP, JR, LE, AB); analyzed the data (DPP, JR, $\mathrm{AB}, \mathrm{MJC}$ ); wrote and revised the manuscript (DPP, MJC); all authors approved the final version of the manuscript.
Financial/Material Support: This study was funded by the Aldo Leopold Wilderness Institute, Montana Institute on Ecosystems, and the University of Montana. MJC acknowledges support from the Simons Foundation (award 329108).

Disclosures: None.

\section{References}

1. The Wilderness Act. (16 USC (note)) 1964:1131-1136.

2. Cole DN, Landres PB. Threats to wilderness ecosystems: impacts and research needs. Ecol Appl. 1996;6(1):168-84.

3. Cilimburg A, Monz C, Kehoe S. Wildland recreation and human waste: a review of problems, practices, and concerns. Environ Manage. 2000;25(6):587-98.

4. Monz CA, Pickering CM, Hadwen WL. Recent advances in recreation ecology and the implications of different relationships between recreation use and ecological impacts. Front Ecol Environ. 2013;11(8):441-6. 
5. Apollo M. The good, the bad and the ugly - three approaches to management of human waste in a high-mountain environment. Int J Environ Stud. 2017;74(1):129-58.

6. McLaughlin JB, Gessner BD, Bailey AM. Gastroenteritis outbreak among mountaineers climbing the west buttress route of Denali-Denali National Park, Alaska, June 2002. Wilderness Environ Med. 2005;16(2):92-6.

7. Meyer DJ, Costantino A, Spano S. An assessment of diarrhea among long-distance backpackers in the Sierra Nevada. Wilderness Environ Med. 2017;28(1):4-9.

8. Devane ML, Moriarty E, Weaver L, Cookson A, Gilpin B. Fecal indicator bacteria from environmental sources; strategies for identification to improve water quality monitoring. Water Res. 2020;185:116204.

9. Layton A, McKay L, Williams D, Garrett V, Gentry R, Sayler G. Development of Bacteroides 16S rRNA gene TaqMan-based real-time PCR assays for estimation of total, human, and bovine fecal pollution in water. Appl Environ Microbiol. 2006;72(6):4214-24.

10. Dick LK, Bernhard AE, Brodeur TJ, Santo Domingo JW, Simpson JM, Walters SP, et al. Host distributions of uncultivated fecal Bacteroidales bacteria reveal genetic markers for fecal source identification. Appl Environ Microbiol. 2005;71(6):3184-91.

11. Kabiri L, Alum A, Rock C, McLain JE, Abbaszadegan M. A tool box strategy using Bacteroides genetic markers to differentiate human from non-human sources of fecal contamination in natural water. Sci Total Environ. 2016;572:897-905.

12. Green HC, Haugland RA, Varma M, Millen HT, Borchardt MA, Field KG, et al. Improved HF183 quantitative real-time PCR assay for characterization of human fecal pollution in ambient surface water samples. Appl Environ Microbiol. 2014;80(10):3086-94.

13. Reischer GH, Ebdon JE, Bauer JM, Schuster N, Ahmed W, Aström J, et al. Performance characteristics of qPCR assays targeting human- and ruminant-associated Bacteroidetes for microbial source tracking across sixteen countries on six continents. Environ Sci Technol. 2013;47(15):8548-56.

14. Bernhard AE, Field KG. Identification of nonpoint sources of fecal pollution in coastal waters by using host-specific 16S ribosomal DNA genetic markers from fecal anaerobes. Appl Environ Microbiol. 2000;66(4):1587-94.

15. Paruch L, Paruch AM, Buseth Blankenberg A-G, Bechmann M, Mæhlum T. Application of host-specific genetic markers for microbial source tracking of faecal water contamination in an agricultural catchment. Acta Agr Scand B-S P. 2015;65(sup2):164-72.
16. Fiksdal L, Maki J, LaCroix S, Staley J. Survival and detection of Bacteroides spp., prospective indicator bacteria. Appl Environ Microbiol. 1985;49(1):148-50.

17. Kreader CA. Design and evaluation of Bacteroides DNA probes for the specific detection of human fecal pollution. Appl Environ Microbiol. 1995;61(4):1171-9.

18. Reischer G, Kasper D, Steinborn R, Farnleitner A, Mach R. A quantitative real-time PCR assay for the highly sensitive detection of human faecal influence in spring water from a large alpine cachment area. Lett Appl Microbiol. 2007;44(4):351-6.

19. Shanks OC, Atikovic E, Blackwood AD, Lu J, Noble RT, Santo Domingo J, et al. Quantitative PCR for detection and enumeration of genetic markers of bovine fecal pollution. Appl Environ Microbiol. 2008;74(3):745-52.

20. Lamendella R, Santo Domingo JW, Yannarell AC, Ghosh S, Di Giovanni G, Mackie RI, et al. Evaluation of swine-specific PCR assays used for fecal source tracking and analysis of molecular diversity of swine-specific "Bacteroidales" populations. Appl Environ Microbiol. 2009;75(18):5787-96.

21. Hold GL, Pryde SE, Russell VJ, Furrie E, Flint HJ. Assessment of microbial diversity in human colonic samples by $16 \mathrm{~S}$ rDNA sequence analysis. FEMS Microbiol Ecol. 2002;39(1):33-9.

22. Cao Y, Raith MR, Griffith JF. Droplet digital PCR for simultaneous quantification of general and human-associated fecal indicators for water quality assessment. Water Res. 2015;70:337-49.

23. Fremaux B, Boa T, Yost CK. Quantitative real-time PCR assays for sensitive detection of Canada goose-specific fecal pollution in water sources. Appl Environ Microbiol. 2010;76(14):4886-9.

24. Derlet RW, Carlson JR. An analysis of wilderness water in Kings Canyon, Sequoia, and Yosemite National Parks for coliform and pathologic bacteria. Wilderness Environ Med. 2004;15(4):238-44.

25. Derlet RW, Carlson JR. Coliform bacteria in Sierra Nevada wilderness lakes and streams: what is the impact of backpackers, pack animals, and cattle? Wilderness Environ Med. 2006;17(1):15-20.

26. Forrester BJ, Stott TA. Faecal coliform levels in mountain streams of winter recreation zones in the Cairngorms National Park, Scotland. Scot Geogr J. 2016;132(3-4):246-56.

27. Harwood VJ, Staley C, Badgley BD, Borges K, Korajkic A. Microbial source tracking markers for detection of fecal contamination in environmental waters: relationships between pathogens and human health outcomes. FEMS Microbiol Rev. 2014;38(1):1-40. 